The effect of interpersonal communication and self-adjustment to the work readiness of vocational high school students

\title{
Tentama, Fatwa
}

Universitas Ahmad Dahlan Yogyakarta, Indonesia (fatwa.tentama@psy.uad.ac.id)

Subardjo, Subardjo

Universitas Ahmad Dahlan Yogyakarta, Indonesia (subardjo@law.uad.ac.id)

Merdiaty, Netty

Universitas Bhayangkara Jakarta Raya, Indonesia (netty.merdiaty@dsn.ubharajaya.ac.id)

Asti Mulasari, Surahma

Universitas Ahmad Dahlan Yogyakarta, Indonesia (surahma.mulasari@ikm.uad.ac.id)

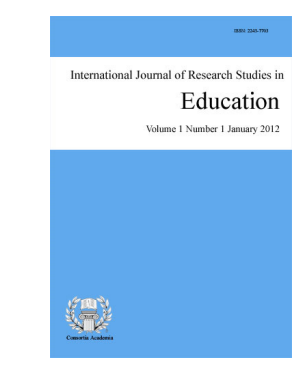

ISSN: 2243-7703 Online ISSN: 2243-7711

OPEN ACCESS

\section{Abstract}

Interpersonal communication and self-adaptation are two factors that can influence the work readiness of students. This study aims to find out the effect of interpersonal communication and self-adaptation to students' work readiness. The subjects in this study were students of class XII of SMK Negeri 1 Seyegan totaling 174 students. The sampling technique is cluster random sampling. Methods of data collection in this study are work readiness scale, interpersonal communication scale, and self-adaptation scale. Meanwhile, data analysis is multiple linear regression analysis. The results of data analysis showed a very significant effect of interpersonal communication and self-adjustment simultaneously on work readiness, with an $\mathrm{F}$ value of 74.382 and a significance level $(p)$ of $.000(p<.01)$. Having better interpersonal communication and adjustment of students, the better work readiness of students and the worse the interpersonal communication and adjustment of students, the lower work readiness of students.

Keywords: interpersonal communication; self-adjustment; work readiness 


\section{The effect of interpersonal communication and self-adjustment to the work readiness of vocational high school students}

\section{Introduction}

Vocational High School is an educational institution that prepares or produces human resources ready to work. At this level students are prepared to have the skills so that graduates will be ready to enter the workforce. According to Gibson and Mitchell (2011) Vocational Middle School is education that prepares a career with a particular job or technical field. Meanwhile Behroozi (2014) defines Vocational Middle School as a place to form skilled human resources who are ready to work after graduation. As one of the educational institutions, Vocational High Schools have a vision, mission and goals. The vision of the Vocational High School is to be skilled, have character and be competitive in work. One of the missions of Vocational High Schools is to improve the quality of learning to produce graduates competitive in work. Meanwhile, the aim of Vocational High School is to improve intelligence, knowledge, personality, noble character and skills to live independently.

Based on the understanding, vision and purpose of the Vocational High School, basically Vocational High Schools are work-oriented schools, one of which is to prepare and provide ready-to-work provisions for students as skilled workers with expertise that is ready to be applied in the work. Vocational High School graduates have an important role in the younger generation to achieve the future. Reality in the field shows that the existence of the Vocational High School is currently considered to be lacking in preparing its graduates as workforce ready, meaning that Vocational High Schools that are built with efforts to reduce unemployment in Indonesia actually contribute to unemployment.

Data from the Central Bureau of Statistics shows that the level of open unemployment with a vocational high school background has increased. Unemployment with a vocational high school background in the period of February 2014 was 847,365 people and increased in 2015 by 1,174,366 people. Then, it increased again in 2016 as many as 1,348,327 people and continued to increase in the period of February 2017 as many as 1,383,022 people. The data shows that Vocational High School graduates are the highest contributor to unemployment in Indonesia. Graduated from Vocational High School, which is a ready-to-use employee in the workforce, apparently has no work readiness to work.

Work readiness is an important thing to note, because work readiness is one of the criteria for measuring the workability of individuals with the needs of the workforce (Sasmito, 2017). In line with the opinion of some experts who suggested that one of the attributes that individuals must possess to identify career opportunities and success in getting work directly or indirectly is work readiness (Landrum, Hettich, \& Wilner, 2010). Individuals need to have high work readiness to develop emotional and social attributes in deepening conceptualization and practices that enable individuals to get work in the future (Bandaranaike \& Willison, 2015). But many entrepreneurs find that some graduates lack work readiness for long-term success (Casner-Lotto \& Barrington, 2006).

The impact resulting from the availability of work readiness is to encourage individuals to improve mobility, produce individuals who are flexible, skilled, and qualified (Andrews \& Higson, 2008). In addition, individuals who have work readiness describe their willingness and commitment to engage in changes related to the work they want (Farkas \& Nicolellis, 2004). Individuals who have work readiness tend to be more able to operationalize affective skills, utilize emotional and social attributes and join job-specific cognitive skills to help optimize individual workability (Bandaranaike \& Willison, 2015).

Work readiness are the extent to which individuals are considered to have the knowledge and skills to work independently (Levett-Jones, Gersbach, Arthur, \& Roche, 2011). Work readiness can be said as an individual's 
readiness to adapt to the demands of culture and workplace (Parker, 2011). According to Kwok, Gujral, and Chan (2014) work readiness is the extent to which individuals have attitudes, skills, and knowledge that can prepare themselves for success in the workplace. Meanwhile according to Bandaranaike and Willison (2015) work readiness is a bridge that connects work-oriented learning with the skills needed by the world of work.

According to Brady (2009), the work readiness is formed through six aspects, namely 1). Responsibility, responsible individuals will complete the task on time and strive to comply with the standards set. This responsibility is closely related to discipline. Responsibilities include maintaining the timeliness of work, meeting work quality standards, focusing on work, working well even if not supervised, and maintaining work practice equipment to complete tasks. 2). Flexibility, flexible individuals are able to adapt to changes and demands of the environment. Individuals believe that environmental conditions are always changing. Individuals realize that everyone may need to be more active and ready to adapt to changes in schedules, assignments, locations, and hours of time. Flexible individuals are able to adjust to the demands of work and their changes. Flexibility includes the ability to be more active with demands, the ability to do different tasks, the ability to accept various environmental changes, the ability to follow applicable rules and the ability to work overtime. 3). Skills, skills include mastery of abilities in the field they already have, the ability to understand themselves related to work, the ability to use work tools in accordance with the procedures of use and effort to learn new skills. 4). Communication, individuals who are ready to work have communication skills that allow individuals to connect interpersonally with the people around them. Communication includes the ability to follow directions in carrying out tasks, the ability to ask for help related to tasks, the ability to work well together, have a sense of trust with others, have a supportive attitude, have an open attitude and accept feedback or criticism. 5). Self-view, is a belief in a person's ability to carry out tasks. In this case the view of self includes the ability to understand themselves, the ability to respect themselves, the ability to control or control themselves, the ability to evaluate themselves, trust in the ability to carry out tasks. 6). Health and safety, individuals who are ready to work to maintain personal hygiene and tidiness. Workers remain alert to be physically and mentally healthy. The component of occupational health and safety includes compliance to follow policies and abandoning restrictions, practicing health and safety behavior, carrying out duties in accordance with existing procedures, maintaining personal hygiene and tidiness, ability to control stress and fatigue.

\subsection{Interpersonal communication towards work readiness}

Interpersonal communication skills are one of the factors that can improve individual work readiness, because interpersonal communication skills are one of the basic skills that dominate workplace needs (McNamara, 2009). It is needed for everyday life, especially in relation to finding work and it is also a skill believed to be able to improve the work readiness of individuals (Paulrajan, 2011). Walker, Storey, Costa, and Leung (2015) in the study propose that individuals need special skills in relation to work readiness, the factors that are referred to include interpersonal communication skills. Meanwhile, the low work readiness in individuals is caused by poor interpersonal communication skills (Taylor, 2007).

Allen, Attner, and Plunkett (2007) define interpersonal communication as direct face-to-face conversation or voice-to-voice conversation that allows direct feedback. Interpersonal communication is a symbol exchange that includes communication characteristics such as listening, influencing, using nonverbal communication, and so on to achieve interpersonal goals that depend on sending messages and receiving messages between two or more individuals (Canary, Cody, \& Manusov, 2008). According to Adler, Rosenfeld, and Proctor (2009) interpersonal communication is the quality of communication that occurs when individuals treat each other as unique individuals, regardless of the context in which interactions occur or the number of people involved. Meanwhile according to Udensi and Akor (2013) interpersonal communication is the process of sending and receiving messages between two or more people who are interdependent with each other to communicate ideas, thoughts, and feelings. 


\subsection{Self-adjustment towards work readiness}

One of the factors believed to be able to improve the work readiness of individuals is their self-adjustment (Caballero, Walker, \& Fuller-Tyszkiewicz, 2011). Self-adjustment is seen as an important lifelong resource to maintain work readiness (Savickas, 2011). In addition, self-adjustment abilities are proven to be able to positively help individuals for their career continuity (Coetzee, Ferreira, \& Potgieter, 2015). Individuals with self-adjustment abilities can make changes related to work and improve individual career opportunities in the workforce (Mohd Yusof, Mustapha, Syed Mohamad, \& Bunian, 2012).

Self-adjustment is a cognitive process for changing expectations, revaluing, and accepting other people's appearance or culture in a new environment (Morling \& Evered, 2006). According to Rousseau, Aube, and Savoie (2006) self-adjustment is the development and implementation of changes aimed at an environment to change unwanted behavior. Chang (2007) defines self-adjustment as referring to small changes when individuals seek intentional contact in a new environment that is unknown to them then develops a positive attitude in that environment to obtain new knowledge about the culture in the environment so that the environment becomes a part of him. Meanwhile, according to Zykov (2016) self-adjustment refers to the individual's personal flexibility to comply with a rule or culture in a particular environment to fulfill his expectations.

Based on the explanation above, the effect of interpersonal communication and self-adjustment on work readiness can be illustrated in the figure 1 below:
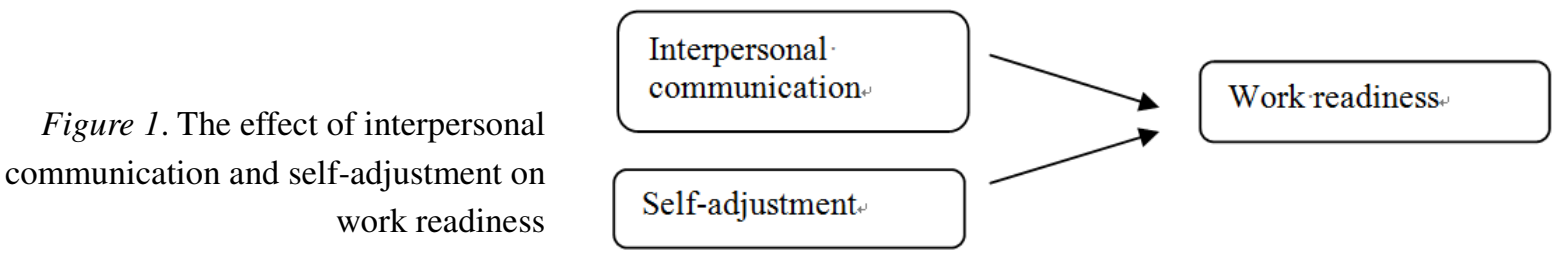

The purpose of this study was to determine the effect of interpersonal communication and Self-adjustment to the work readiness of vocational high school students.

\section{Method}

\subsection{Population and Samples}

The population in this study was all students of Grade XII State Vocational High School 1 Seyegan, Sleman Yogyakarta. Vocational High School consisting of 14 classes totaling 423 students. Each class consists of 30 students. The sample in this study consisted of 6 classes obtained randomly with 174 students in class XII. The sample selection was done by randomly raffling from 14 classes which finally got 6 classes as the research sample.

\subsection{Research Subject}

The subjects in this study were 174 students at State Vocational High School 1 Seyegan, Sleman, Yogyakarta and those who sat in class XII. The selection of research subjects was done randomly (randomized), with cluster random sampling technique

\subsection{Measuring Instrument}

In this study the scaling model used for the work readiness scale, interpersonal communication scale, and self-adjustment scale is a Likert scale. Work readiness was revealed by using the work readiness scale that refers to the aspects of work readiness according to Brady (2009), namely: responsibility, flexibility, skills, speaking ability, self-view, health and safety. An example of a work readiness scale item is "I complete the assignment on 
time", "I can do varied tasks", "I can use the practical tools well", "I am willing to accept criticism and feedback from others" , I am sure I can do the assignments given, and "I follow safety procedures during fieldwork".

Interpersonal communication is revealed by the scale of interpersonal communication which refers to aspects of interpersonal communication according to Devito (2009), namely: openness, positive behavior, empathy, supportive behavior, and similarity. An example of an interpersonal communication scale item is "I need criticism and suggestions from others for my work", "I like to discuss with my friends", "When given the opportunity to speak at a meeting, I will express my opinion", "I respect the opinions of others different from me"," I like to tell my difficulties in doing assignments to friends", and "If I don't understand the material, I will ask the teacher or a friend who is more understanding".

Self-adjustment is revealed by using an adjustment scale that refers to aspects of self-adjustment according to Schneiders (1999), namely: control of excessive emotions, minimal self-defense mechanisms, minimal personal frustration, rational consideration and self-directed ability, ability to learn and make use of past experiences, and realistic and objective attitudes. An example of a self-adjustment scale item is "I continue to be patient in facing problems", "I think failure is a natural thing in dealing with problems". For me, success is only obtained when the surrounding conditions are favorable", "I keep trying even though I experience failure", and "I refuse to accept assignments if I am unable to do them."

\subsection{Validity and Reliability of Measuring Instrument}

Select items on a scale that is by looking at item discrimination. As the selection criteria for items based on corrected item-total correlation criteria are $\geq .30$. All items that achieve a corrected item-total correlation of at least 0.30 , item discrimination are considered satisfactory. On a scale that does not reach the corrected item-total correlation criteria, the item will be eliminated, because by removing the item, the Cronbach alpha reliability coefficient of the scale will be higher.

On the work readiness scale with 58 test subjects the results of the reliability coefficient were .866 . The index of item difference power (corrected item-total correlation) moves from .293 to .591. Valid and reliable items that are used for research are 24 items.

On the scale of interpersonal communication with the trial subjects 58 students obtained the reliability coefficient of 0.865 . The corrected item-total correlation index moves from .310 to .589 . Valid and reliable items that are used for research are 20 items.

On a scale of self-adjustment with 58 students the test subjects obtained the reliability coefficient of 0.872 . The index of the power difference item (corrected item-total correlation) moves from .311 to .649. Valid and reliable items that are used for research are 18 items.

\subsection{Data Analysis}

The method for analyzing data uses parametric statistical methods. Data analysis was performed using SPSS 17.0 for windows, through multiple regression techniques, namely a statistical analysis technique to determine the effect of two independent variables (interpersonal communication and self-adjustment) on one dependent variable (work readiness).

\section{Result}

\subsection{Prerequisite test}

Normality Test - Based on the results of the analysis of the normality test shown in table 1, it is known that the significance values of work readiness, interpersonal communication, and self-adjustments are .188, .074 
Tentama, F., Subardjo, S., Merdiaty, N., \& Asti Mulasari, S.

and $.421, p>.05$ so that each data is normally distributed meaning there is no difference between distribution of sample scores and population scores in other words the sample used is able to represent the population.

\section{Table 1}

Normality test

\begin{tabular}{lccc}
\hline \multicolumn{1}{c}{ Variable } & Skor K-SZ & Sig. & Explanation \\
\hline Work readiness & 1.087 & .188 & Normal \\
Interpersonal communication & 1.285 & .074 & Normal \\
Self-adjustment & .880 & .421 & Normal \\
\hline
\end{tabular}

Linearity Test - The results of the linearity test obtained F linearity on interpersonal communication on work readiness of 78.257 with a significance level $(p)$ of .000 which means linear or there is a line that connects interpersonal communication variables to work readiness. The linearity test results of self-adjustment to work readings obtained $\mathrm{F}$ linearity of 119.858 with a significance level $(p)$ of .000 which means linear or there is a straight line that connects self-adjustment to work readiness.

Table 2

Linearity Test

\begin{tabular}{lcccc}
\hline \multicolumn{1}{c}{ Variable } & $\mathrm{F}$ & Significance & Criteria & Explanation \\
\hline Interpersonal Communication & 78.257 & .000 & $p<.05$ & Linear \\
Self-adjustment & 119.858 & .000 & $p<.05$ & Linear \\
\hline
\end{tabular}

Multicollinearity Test - The multicollinearity test was conducted to ensure that there was no multicollinearity relationship between the two independent variables. The rule used to determine that there is no multicollinearity relationship is to see tolerance $>.1$ and $\mathrm{VIF}<10$. Based on the analysis results show that interpersonal communication and self-adjustment have VIF values $=1.387(\mathrm{VIF}<10)$ and tolerance $.721=$ (tolerance $>$.1) then, there is no multicollinearity between interpersonal communication and self-adjustment.

Table 3

Multicollinearity test

\begin{tabular}{lccc}
\hline \multicolumn{1}{c}{ Variable } & Tolerance & VIF & Explanation \\
\hline Interpersonal Communication & .721 & 1.387 & No multicollinearity \\
Self-adjustment & .721 & 1.387 & No multicollinearity \\
\hline
\end{tabular}

\subsection{Multiple regression Test}

Based on the results of the regression test analysis, it was found that the magnitude of the influence of interpersonal communication on work readings was $(\mathrm{t})=4.762$ with a significance level of $=.000, p<.01$ ), which means that there is a very significant influence on interpersonal communication on work readiness in students in State Vocational High School 1 Seyegan. While the results of the regression test analysis adjust to work readiness obtained a value $(\mathrm{t})$ of $=7.018$ with a significance level of $=.000, p<.01$, which means that there is a very significant effect of self-adjustment to work readiness on students in State Vocational High School 1 Seyegan.

Table 4

The result of correlation test between variables

\begin{tabular}{lcccl}
\hline \multicolumn{1}{c}{ Variable } & $t$ & Sig & Criteria & \multicolumn{1}{c}{ Explanation } \\
\hline $\begin{array}{l}\text { Interpersonal communication toward work } \\
\text { readiness } \\
\text { Self-adjustment to work readiness }\end{array}$ & 4.762 & .000 & $p<.01$ & $\begin{array}{l}\text { There is influence and } \\
\text { very significant }\end{array}$ \\
& 7.018 & .000 & $p<.01$ & $\begin{array}{l}\text { There is influence and } \\
\text { very significant }\end{array}$ \\
\hline
\end{tabular}


The results of the regression analysis simultaneously showed the results of the F Test of $=74.382$ with a significance level of $(p)=.000, p<.01)$ which means that interpersonal communication and self-adjustment simultaneously were very significant for the work readiness by students in State Vocational High School 1 Seyegan. The magnitude that contributes to interpersonal communication and related to work is readiness by the assessment of Adjusted R Square $=.459$ which means it supports interpersonal communication and that is distributed at $45.9 \%$ and at $54.1 \%$ depending on the variable in question.

Table 5

Multiple Regression Test Result

\begin{tabular}{lccccc}
\multicolumn{1}{c}{ Variable } & $\begin{array}{c}\text { Adjusted R } \\
\text { Square }\end{array}$ & $F$ & Sig & Criteria & Explanation \\
\hline $\begin{array}{l}\text { Interpersonal communication, } \\
\text { self-adjustment towards work readiness }\end{array}$ & .459 & 74.382 & .000 & $p<.01$ & $\begin{array}{l}\text { There is influence } \\
\text { and very significant }\end{array}$ \\
\hline
\end{tabular}

\section{Discussion}

The results of the multiple regression analysis of the influence of interpersonal communication and self-adjustment to students work readiness obtained results that interpersonal communication and self-adjustment simultaneously play a role in influencing students' work readiness. Based on these results, it is indicated that the first hypothesis is accepted so that the work readiness variable can be predicted based on interpersonal communication and self-adjustment. Both interpersonal communication and self-adjustment contribute $45.9 \%$ to work readiness so that the remaining $54.1 \%$ can be influenced by other factors. There are many factors that influence work readiness including organizational acumen, social intelligence, characteristics, personal and work competencies (Caballero, Walker, \& Fuller-Tyszkiewicz, 2011). Partially the results of this study indicate that interpersonal communication contributes to work readiness of $17.5 \%$ and self-adjustment contributes $29 \%$ to work readiness. The effect of self-adjustment on work readiness is more dominant than interpersonal communication on work readiness in students at State Vocational High School 1 Seyegan.

In the second hypothesis proposed, it was found that there was an influence of interpersonal communication variables on students' work readiness so that the hypothesis was accepted. The results obtained are in line with the findings of Jackling (2007) who also support previous research and broaden understanding of the mechanisms by which interpersonal communication contributes to improving work readiness. The results of Jackling and De Lange (2009) also show that the low work readiness of individuals is caused by the lack of skills needed to find work such as interpersonal communication skills.

According to Jones and Toburen (2009) one of the skills needed to improve work readiness is interpersonal communication skills. Developing interpersonal communication skills allow individuals to have better work readiness (McGovern, Corey, Cranney, Dixon, Holmes, Kuebli, Ritchey, Smith, \& Walker, 2010; Trapp, Banister, Ellis, Latto, Miell, \& Upton, 2011). Interpersonal communication in students is indicated by the openness of various things in school such as students being able to express their opinions openly, being able to establish relationships in interacting with others, and students have positive feelings and positive behaviors towards others and teachers, so cooperation in carrying out tasks and practices in the school can be well established. Besides, students who have interpersonal communication, students can empathize with others, be active in getting information, have a willingness to hear different views and are willing to accept the opinions of others, and feel they have similarities with each other so that these things make students adaptable, has the skills needed to complete tasks, speaking skills, beliefs and self-confidence needed to prepare for work (work readiness). Mirza, Jaffri, and Hashmi (2014), communication skills can improve the work readiness of graduates. Some entrepreneurs consider that interpersonal relationships are skills that individuals need to have work readiness (Zhang \& Zou, 2013).

In the third hypothesis proposed, it was found that there was an effect of the self-adjustment variable on the 
work readiness of students so that the hypothesis was accepted. The results obtained are supported by assumed theory and also some other research findings that find that to improve the work readiness of individuals must be able to adjust to a variety of jobs (Hess, Jepsen, \& Dries, 2012). Self-adjustment is a psychosocial resource for self-regulation needed by individuals to successfully manage work readiness (Savickas, 2013). Further studies have found that learning orientation is associated with a higher level of self-esteem including career management strategies related to taking responsibility for career decision making and goal implementation, gathering job information and being confident about the abilities they have to implement career goals and solve problems to improve work readiness (Del Corso, 2013). Students who have good self-adjustment mean that students have control and emotional calm in facing various tasks and problems in their environment, are willing to acknowledge failures experienced and try to get up to achieve the goals set, have optimism, are able to learn and utilize past experiences to achieve goals and have a realistic and objective attitude towards their abilities. These things make students have a sense of responsibility, flexibility, skills, and a realistic self-view to be more ready to work in the face of various situations in the world of work.

Thus interpersonal communication and self-adjustment have an important role in preparing Vocational High School students to be ready to work in the industrial world. Students who have work readiness are shown by their sense of responsibility, flexibility, skill, ability to speak, self-view, health and safety in carrying out their duties and obligations in school, whether in attending school lessons, practicing in the laboratory, field work practices and work internships in industry / companies.

Research on work-readiness is still rarely done both in Indonesia and abroad. Previous studies only discussed work-readiness which is still limited to work-readiness in employees at an agency. Some of these studies include Cavanagh, Burston, Southcombe, and Bartram (2015) who conducted research on hospital employees (nurses) in Victoria regional hospitals, Australia with the aim of exploring the relationship between work-readiness and a number of work outcomes, such as job satisfaction, work engagement, and intention to remain. The research conducted by Baumann, Crea - Arsenio, Hunsberger, Fleming-Carroll, and Keatings, (2019) focuses on employees of pediatric specialty hospitals in Ontario, Canada consisting of managers, nurses and counselors with the aim of knowing what factors can improve employee work-readiness. While the renewal of this research focuses on the work-readiness of Vocational High School students, which are educational institutions that prepare students and graduates to get jobs and have the skills needed in their jobs. The concept of work-readiness in this research is the ability students have to be ready to work by showing the existence of responsibility, flexibility, skills, communication, self-view, and health and safety.

The implications of this study can provide insight and awareness to students, parents, and teachers. This study shows that interpersonal communication and self-adjustment as a form of soft skills have a role for class XII students in supporting the skills, knowledge and understanding gained in the school environment to be applied in the workforce after graduation. Parents and teachers must be able to create a positive learning environment so students can create a conducive and effective learning environment. The existence of a positive environment will make students easy to adapt and interact with the people around them so that students can optimally get the skills and knowledge to prepare themselves in the world of work. The results of this study can also be used as a reference for developing training modules specifically adaptation training and interpersonal communication training that have contributed to addressing work-readiness problems in Vocational High School students. Thus students will be better prepared to get a job and quickly adapt to their work after graduating from Vocational High School.

\section{Conclusion}

Based on the results of the analysis of research data, the conclusions that can be taken in this study include: 1) simultaneously there is a very significant influence of interpersonal communication and adjustment to students' work readiness. 2) There is a very significant effect of interpersonal communication on students' work readiness. 3) There is a very significant effect of adjustment to students' work readiness. Self-adjustment is more 
Effect of interpersonal communication and self-adjustment to work readiness of vocational high school students dominant in influencing work readiness than interpersonal communication.

Acknowledgements: The research reported in this manuscript is part of the fundamental research of the first author, funded by the Institute of Research and Community Service (LPPM) Ahmad Dahan University in letter Number PF-109/SP3/LPP-UAD/IV/2017. Appreciation goes to funder and research respondents.

\section{References}

Adler, R. B., Rosenfeld, L. B., \& Proctor, R. F. (2009). Interplay: The process of interpersonal communication. New York: Oxford University Press.

Allen, G. S., Attner, R. F., \& Plunkett, W. R. (2007). Management. Cincinnati: South Western Publication.

Andrews, J., \& Higson, H. (2008). Graduate employability, 'soft skills' versus 'hard' business knowledge: A European study. Higher Education in Europe, 33(4), 411-422. https://doi.org/10.1080/03797720802522627

Bandaranaike, S., \& Willison, J. W. (2015). Building capacity for work-readiness: Bridging the cognitive and affective domains. Asia-Pacific Journal of Cooperative Education, 16(3), 223-233.

Baumann, A., Crea-Arsenio, M., Hunsberger, M., Fleming-Carroll, B., \& Keatings, M. (2019). Work readiness, transition, and integration: The challenge of specialty practice. Journal of Advanced Nursing, 75(4), 823-833. https://doi.org/10.1111/jan.13918

Behroozi, M. (2014). A survey about the function of technical and vocational education: An empirical study in Bushehr city. Procedia-Social and Behavioral Sciences, 143, 265-269. https://doi.org/10.1016/j.sbspro.2014.07.401

Brady, R. P. (2009). Work readiness inventory administrators' guide. Indianapolis: JIST Publishing, Inc.

Caballero, C. L., Walker, A., \& Fuller-Tyszkiewicz, M. (2011). The work readiness scale (WRS): Developing a measure to assess work readiness in college graduates. Journal of Teaching and Learning for Graduate Employability, 2(2), 41-54. https://doi.org/10.21153/jtlge2011vol2no1art552

Canary, D. J., Cody, M. J., \& Manusov, V. L. (2008). Interpersonal communication: A goals-based approach. New York: Bedford/St. Martin's.

Casner-Lotto, J., \& Barrington, L. (2006). Are they really ready to work? New York: The Conference Board.

Cavanagh, J., Burston, M., Southcombe, A., \& Bartram, T. (2015). Contributing to a graduate-centred understanding of work readiness: An exploratory study of Australian undergraduate students' perceptions of their employability. The International Journal of Management Education, 13(3), 278-288. https://doi.org/10.1016/j.ijme.2015.07.002

Chang, H. (2007). Cultural autobiography for Christian multicultural educators. International Journal of Christianity \& Education, 14(3), 1-15.

Coetzee, M., Ferreira, N., \& Potgieter, I. L. (2015). Assessing employability capacities and career adaptability in a sample of human resource professionals. SA Journal of Human Resource Management, 13(1), 1-9. https://doi.org/10.4102/ sajhrm.v13i1.682

Del Corso, J. (2013). The theory of career adaptability. New York, NY: Nova Science Publishers.

DeVito, J. A. (2009). Interpersonal communication. New Jersey: Pearson Education.

Farkas, M., \& Nicolellis, D. (2004). Fostering readiness for rehabilitation and employment. Boston, MA: Springer.

Gibson, R. L., \& Mitchell M. H. (2011). Introduction to counseling and guidance. New York: Macmillan Publisher.

Hess, N., Jepsen, D. M., \& Dries, N. (2012). Career and employer change in the age of the 'boundaryless' career. Journal of Vocational Behavior, 81(2), 280-288. https://doi.org/10.1016/j.jvb.2011.10.009

Jackling, B. (2007). The lure of permanent residency and the aspirations and expectations of international students studying accounting in Australia. People and Place, 15(3), 31-41.

Jackling, B., \& De Lange, P. (2009). Do accounting graduates' skills meet the expectations of employers? A 
Tentama, F., Subardjo, S., Merdiaty, N., \& Asti Mulasari, S.

matter of convergence or divergence. Accounting Education: An International Journal, 18(4-5), 369-385. https://doi.org/10.1080/09639280902719341

Jones, D., \& Toburen, M. (2009). Aligning HIRED workshops with work readiness standards. Minneapolis: Center for Urban and Regional Affairs.

Kwok, D., Gujral, M., \& Chan, J. (2014). Work readiness: A study of student intern's self-perception and supervisor evaluation. International Conference on Teaching \& Learning in Higher Education, 1(3). https://doi.org/10.11591/edulearn.v13i2.12677

Landrum, R. E., Hettich, P. I., \& Wilner, A. (2010). Alumni perceptions of workforce readiness. Teaching of Psychology, 37(2), 97-106. https://doi.org/10.1080/00986281003626912

Levett-Jones, T., Gersbach, J., Arthur, C., \& Roche, J. (2011). Implementing a clinical competency assessment model that promotes critical reflection and ensures nursing graduates' readiness for professional practice. Nurse Education in Practice, 11(1), 64-69. https://doi.org/10.1016/j.nepr.2010.07.004

McGovern, T. V., Corey, L. A., Cranney, J., Dixon, W. E., Holmes, J. D., Kuebli, J. E., Ritchey, K., Smith, R. A., \& Walker, S. (2010). Psychologically literate citizens. Washington: American Psychological Association.

McNamara, B. R. (2009). The skill gap: Will the future workplace become an abyss. Techniques: Connecting Education and Careers, 84(5), 24-27.

Mirza, F. M., Jaffri, A. A., \& Hashmi, H. S. (2014). An assessment of industrial employment skill gaps among university graduates: In the Gujrat-Sialkot-Gujranwala industrial cluster, Pakistan. Washington: International Food Policy Research Institute.

Morling, B., \& Evered, S. (2006). Secondary control reviewed and defined. Psychological Bulletin, 132(2), 269-296. https://doi.org/10.1037/0033-2909.132.2.269

Parker, A. J. (2011). Career and technical education and workplace readiness of high school students (Doctoral Dissertation). University of Georgia. Athena.

Paulrajan, R. (2011). Employability skills in Chennai retail market, India. Acta Universitatis Danubius, 7(5), 16-30.

Rousseau, V., Aubé, C., \& Savoie, A. (2006). Teamwork behaviors: A review and an integration of frameworks. Small Group Research, 37(5), 540-570. https://doi.org/10.1177/1046496406293125

Sasmito, A. P. (2017). Work readiness of software engineering student in Batu City. Education and Humanities Research, 116, 67-70. https://doi.org/10.2991/icovet-17.2017.13

Savickas, M. L. (2011). New questions for vocational psychology: Premises, paradigms, and practices. Journal of Career Assessment, 19(3), 251-258. https://doi.org/10.1177/1069072710395532

Savickas, M. L. (2013). Career construction theory and practice. New Jersey: John Wiley \& Sons.

Schneiders, A. A. (1999). Personal adjustment and mental health. New York: Holt, Reinhart and Winston Inc.

Taylor, M. (2007). Generation NeXt goes to work: Issues in workplace readiness and performance. A Collection of Papers on Self-study and Institutional Improvement, 2, 48-55.

Trapp, A., Banister, P., Ellis, J., Latto, R., Miell, D., \& Upton, D. (2011). The future of undergraduate psychology in the United Kingdom. York: Higher Education Academy Psychology Network. https://doi.org/10.1037/e717892011-001

Udensi, J. N., \& Akor, P. U. (2013). Functions of interpersonal communication in rendering reference services in two University libraries in Nigeria. Library Philosophy and Practice, 1-46.

Walker, A., Storey, K. M., Costa, B. M., \& Leung, R. K. (2015). Refinement and validation of the work readiness scale for graduate nurses. Nursing Outlook, 63(6), 632-638. https://doi.org/10.1016/j.outlook.2015.06.001

Zhang, X., \& Zou, X. (2013). University students' employability skills model based on Chinese employer perspective. Journal of Human Resource and Sustainability Studies, 1, 29-33. https://doi.org/10.4236/jhrss.2013.13005

Zykov, S. V. (2016). Crisis management for software development and knowledge transfer. Cham: Springer International Publishing. https://doi.org/10.1007/978-3-319-42966-3 